\title{
KRITIK TRADISI ILMIAH BARAT: MENYOROT FUNGSIONALITAS \\ METODE ILMIAH DALAM PEMBANGUNAN MANUSIA SEUTUHNYA
}

\author{
Oleh: \\ Fajar Syarif \\ Universitas Pamulang \\ fajarsyarif@gmail.com
}

\begin{abstract}
This research discusses the development of Western Science, which utters a negative impact in the shaping of society and men as human. The prime factor is the understanding of "Free Value" which is known as the Science of Free Value Morality. The result of the development of this science can not be controlled, which impact to crisis of morality, this research proves that reform and development of scientific traditions must begun from cleaning up epistemology and science must be known culturally.
\end{abstract}

Keywords : western scientific tradition, scientific method, epistemology and acsiology

\section{Pendahuluan}

Terdapat dua persoalan yang dilematis dalam perkembangan masyarakat modern. Di satu sisi, salah satu tanda majunya sebuah masyarakat adalah kuatya tradisi ilmiah, sehingga perkembangan masyarakat harus didorong untuk mengembangkan hal ini. Namun, di sisi lain, perkembangan tradisi ilmiah Barat, yang dikenal sebagai kejayaan peradaban masa kini, nyatanya, terjadi krisis moral.

Problem dilematis seperti ini banyak diakui oleh banyak kalangan, terutama berkaitan dengan teknologi. Memang, pada tahap tertentu, teknologi memberikan banyak manfaat kepada masyarakat. Namun, dalam perkembangannya, ternyata teknologi terpisah dengan nilai-nilai moral. Akhirnya, hal itu menjadi menimbulkan problem baru dalam masyarakat.

Dalam konteks demikian, penulis menilai, perlunya perspektif kultural dan perspektif Islam diangkat sebagai sikap umat Islam dalam menyelesaikan problem dilematis tersebut, dengan tujuan, tradisi ilmiah yang telah dicapai oleh Barat, dapat dipertahankan, dan krisis yang diakibatkannya juga dapat diatasi. Dalam rangka inilah, tulisan ini diharapkan dapat memberikan perpsektif berbeda dalam mengembangkan ilmu pengetahuan. 


\section{Memasyarakatkan ilmu; Penelitian Ilmiah dan Pendidikan Ilmiah}

Tidak semua pengetahuan dapat dikategorikan sebagai ilmu; ilmu meminta ketelitian tertentu dari sejumah pengalaman yang diperoleh manusia. Metode ilmiah yang rumit adalah "satu-satunya" syarat pengujian pengetahuan ke-ilmu-an; maka serumit itu pula kita harus membedakan sebuah budaya (ilmiah), yang tak lain adalah akumulasi dari sekian banyak nilai-nilai yang hidup di sebuah komunitas masyarakat. Benarkah ada budaya ilmiah di Indonesia? Pertanyaan ini menjadi penting dijawab untuk melanjutkan tujuan di awal, membedakan budaya ilmiah dan budaya lainnya.

Budaya ilmiah dapat diartikan sebagai nilai-miai ilmiah yang sudah mengakar dalam kehidupan masyarakat yang telah lama menghayati serta mengamalkannya. Nilai-nilai itu terus berkembang dari masa ke masa sesuai dengan temuan-temuan dan kesadaran manusia. Berkenaan dengan nilai-nilai lain yang turut mewarnai kepribadian sebuah bangsa, dapat dikatakan, nilai-nilai ilmiah adalah motor penggerak perubahan dan kemajuan nilai-nilai yang lain (Jujun S, 2005, h. 272); politik, ekonomi, seni, bahasa ke arah yang lebih dewasa, sejalan dengan prinsip ilmu, dinamis dan terbuka.

Namun persoalannya, kehidupan politik, ekonomi dan budaya secara umum yang kita alami justru terjerat dalam dunia krisis yang akut. Akankah ini sebuah petanda bahwa budaya ilmiah tidak atau belum berfungsi secara maksimal? Dapat dibangun sebuah logika: dinamisitas ilmu yang berkembang di Indonesia seharusnya mampu mewujudkan kehidupan yang lebih maju dan sejahtera. Ataukah justru budaya politik, ekonomi dan yang lainnya yang menghambat dinamisitas keilmuan di negeri ini; represi politik, krisis ekonomi atau norma (agama, adat)? Terlepas dari semua kemungkinan itu, persoalan ini dapat dikerucutkan: belum adanya budaya ilmiah di Indonesia (!).

Bila ditinjau dari segi keilmuan, perkembangan zaman harusnya mendorong peningkatan mutu pendidikan sehingga mampu memberikan kontribusi bagi pembangunan bangsa dan negara. Evaluasi ini tidak mungkin lepas dari tinjauan terhadap kegiatan ilmiah, baik secara teoritik ataupun praktik. Disinilah perlunya kritik epistemologis terhadap perkembangan keilmuan yang ada.

Epistemologi dapat dipahami sebagai sisi operasional dari suatu ilmu, atau dengan bahasa lain, epistemologi adalah seperangkat sistem metodik dalam memperoleh dan menyusun tubuh pengetahuan dengan beberapa karakteristiknya; 
didasarkan pada pengalaman empiris; bersifat logis dan teruji secara verifikatif (Jujun S, 1986, h. 6). Dari ketiga karakter itu, perlu disimpulkan, ilmu hanyalah terbatas pada pengalaman manusia yang logis, empiris dan verifikatif, untuk membedakan ilmu dari pengetahuan dan pengalaman manusia selain ilmu, atau pengalaman di luar jangkauan manusia. Dalam awal kajian ini, penulis ingin menekankan ciri yang ketiga, syarat verifikasi.

Verifikasi dapat dipahami sekadar empirisisme ilmu, dalam arti ilmu bukan hanya pengetahuan yang dapat dibuktikan melainkan juga harus dipahami, bahwa ilmu adalah pengalaman manusia yang harus diuji kebenarannya. Detailnya, suatu pengetahuan yang disebut ilmu adalah ilmiah-isasi terhadap pengalaman seseorang saat menemukannya, juga terbatas pada (alat/metode) pembuktian zamannya. Sementara pengalaman (sejarah) manusia tidak berjalan secara linear deterministik, melainkan penuh dengan improvisasi dan perkembangan di sana-sini. Atau dalam ungkapan hiperbolik, dalam satu kurun pun, pengalaman manusia yang satu dengan yang lainnya tidak dapat dipastikan sama. Setidakyna ini, yang disebut sebagai relitivisme ilmiah, seperti dalam pandangan Kukla (2012, h. 23), ketika meletakkan sosiologi pengetahuan sebagai sesuatu yang tidak rigid, kaku, atau paten seperti dalam ilmu alam, yang dapat dipahami sccara pasti.

Penting kemudian disimpulkan, bahwa ilmu lebih tepat dinilai sebagai proses mengetahui secara ilmiah, bukan pengetahuan ilmiah. Sebab ada realitas "yang tak terpikirkan" dalam suatu masa yang muncul "terpikirkan" di masa berikutnya. Jujun S Suriasumantri (1986, h. 7) berkesimpulan, sistem verifikasi menekankan keterbukaan ilmu pada pembuktian secara tidak berkeputusan.

Satu hal yang menurut Jujun menyebabkan keterlambatan perkembangan keilmuan adalah anggapan ilmu sebatas pengetahuan (sebagai hasil dari metode) ilmah, tanpa mengindahkan aspek dinamika yang tersirat dalam verifikasi, yang terbuka; kurangnya pengajaran metodologi, atau pengajaran metodologi yang tidak disertai dengan praktek penelitian ilmiah secara proporsional, sehingga metodologi menjadi hafalan baru di luar materi non-metodologis, semisal pengetahuan filsafat pendidikan sebagai ilmu (bukan) filsafat pendidikan sebagai epistemologi. Ironis akhirnya, seorang mahasiswa berkecenderungan untuk menguasai (hafal) teori-teori itu sebagai jawaban ujian (tengah/akhir) semester. 
Selain pemahaman ilmu (lebih konstruktif) sebagai proses tahu, satu lagi yang perlu ditekankan untuk berupaya memasyarakatkan nilai-nilai ilmiah adalah penelitian ilmiah, yang bersifat integral dengan kegiatan ilmiah. Dengan penekanan ini, dapat diciptakan suatu tradisi "meneliti" bukan "menemukan" yang menjamin perkembangan keilmuan. Di samping mengingat pragmatisme ilmu terbatas pada lokalitas yang sangat sempit.

Setelah mengetahuai belum adanya budaya ilmiah di negeri ini, serta untuk membedakan budaya ilmiah (yang harusnya ada), perlu diupayakan memasyarakatkan ilmu dan budaya berpikir ilmiah, untuk melibatkan seluruh lapisan masyarakat dalam proses pembangunan dalam segala aspeknya.

\section{Aksiologi Ilmu; dari Bebas Nilai ke Fungsionalitas Keilmuan}

Sama sekali aku tak anti teknologi, tapi aku lebih percaya pada hati... (Mahesa Tbrahim/Iwan Fals, 1991). Benarkah pernyataan ironis ini, jika kita pahami ilmu sebagai motor penggerak budaya dan peradaban? Tapi haruskah kita percaya kepada ilmu jika akhirnya terbunuh oleh bahaya ilmu sendiri? Setidaknya kita patut mempertanyakan, mengapa perkembangan keilmuan (di Indonesia) tidak mampu berbicara banyak saat dunia semakin menekan bangsa ini dengan kemajuannya? Dan mengapa kemajuan keilmuan bangsa "barat" justru melemahkan negara-negara berkembang seperti Indonesia? Adakah parokisme ${ }^{1}$ dalam ilmu? Aksiologi ilmu harus bisa menjawab tugas ini.

Kita semua tahu bahwa terdapat banyak hal yang disayangkan dari pesatnya perkembangan ilmu pengetahuan Barat, seperti keprihatinan Aholiab Watloly (2001, h. 203), menilai bahwa,

Dewasa ini perkembangan Ilmu Pengetahuan yang satu bercerai dari pengetahuan yang lainnya. Ilmu bercerai dari moral, moral bercerai dari seni, seni tercerai dari ilmu, dan seterusnya. Keadaan inilah yang banyak disoroti sebagai sumber ketidakbahagiaan manusia modern dewasa ini. Hal ini disebabkan karena pengetahuan yang tidak utuh akan membentuk pula manusia yang tidak utuh.

\footnotetext{
${ }^{1}$ Parokisme adalah istilah yang berkembang dalam lingkungan gereja, untuk membeda jama'at gereja dengan pastur. Tujuannya secara hierarkis yang menandakan keberpihakan ilmu secara rasial/komunal.
} 
Perceraian ilmu dan moral seperti dalam kutipan di atas, setidaknya relevan untuk mengangkat teknologi sebagai satu bukti kemajuan ilmu pengetahuan modern, sekaligus menjadi tanda lahirnya krisis dalam masyarakat modern. Franz Magniz Suseno (1992, h. 56) memberikan beberapa ciri masyarakat modern, di antaranya adalah masyarakat yang berdasarkan industrialisasi. Industrialisasi dalam hal ini merupakan motor penggerak dalam kemajuan masyarakat modern, sedangkan teknologi, diletakkan sebagai alat untuk meneliti kekuatan-kekuatan alam, termasuk manusia sebagai objek materialnya, dengan tujuan memanfaatkannya bagi produksi industrial.

Salah satu contoh krisis kemanusiaan dalam konteks ini, seperti yang diberikan oleh Hadiwardoyo (1990, h. 91) bahwa bioteknologi merupakan salah satu perkembangan teknologi paling mencolok pada abad ini. Tapi, hal itu justru dikhawatikan dapat menghancurkan manusia, seperti atom dan tenaga nuklir, dapat dipergunakan untuk mencukupi kebutuhan energi, tapi juga berpotensi menghancurkan manusia.

Kenyataan ini, juga menjadi keprihatinan Poespowardojo (1989, h. 203) bahwa perkembangan pengetahuan dan teknologi telah menampilkan diri bukan hanya sebagai alat, melainkan sikap. Ini juga diakui oleh Franz Magnis Suseno (1992, h. 57) sebagai suatu perubahan total dalam gaya hidup manusia. Aholiab Watloly (2001, h. 203) juga menyatakan, dalam konteks demikian, manusia dan kemanusiaannya menjadi ajang penelitian dan sekaligus menjadi konteks pengembangan ilmu pengetahuan.

Dengan demikian, dapat diketahui bahwa perkembangan ilmu pengetahuan dengan kecanggihan teknologinya perlu didampingi dengan pertimbangan moral, supaya teknologi tetap diabadikan bagi kepentingan manusia, dalam tradisi ilmiah juga perlu diarahkan untuk membentuk manusia seutuhnya, sebagai aktor dari perkembangan ilmu pengetahua, bukan sebliknya yakni tekologi yang mengendalikannya.

Dari ulasan ini, persoalan menjadi jelas, bahwa kemajuan ilmu pengetahuan dalam masyarakat modern mengarah pada persoalan moral yang harus diangkat kembali sebagai basis epistemologinya. Dan, berbicara persoalan ini, erat kaitannya dengan persoalan aksiologi. 
Secara umum dipahami bahwa aksiologi menyangkut persoalan nilai-nilai yang harus diperhatikan oleh seorang ilmuwan dalam mengupayakan pengembangan ilmunya, yaitu menyesuaikan dengan nilai-nilai yang hidup dalam masyarakatnya. Kenyataan yang menimpa Albert Einstein ${ }^{2}$ dengan penyalahgunaan teori atomnya adalah salah satu kasus yang dibahas relevan dengan kajian ini. Memang di satu sisi, teori atom sangat berguna bagi perkembangan keilmuan, namun di sisi yang lain, kehadiran atom justru menjadi bumerang bagi keselamatan (ke)manusia(an). Einstein pun menyadari bahwa ilmu tanpa agama (moral) adalah buta. Sederhananya timbul keraguan, bagaimana kita akan membudayakan suatu tradisi ilmiah yang justru amoral? Membudayakan kegiatan ilmiah tidak penting (?)

Salah satu kunci persoalan di atas adalah netralitas ilmu dalam kaitannya dengan nilai; ilmu itu bebas nilai. Sebenarnya proposisi di atas tidaklah berarti bahwa ilmu akan berlari tanpa kendali (moral), melainkan melepaskan diri dari dogmatisme yang mengekang perkembangannya. Sejarah netralitas ilmu dapat ditelusuri sejak era Yunani klasik, di mana ontologi baru ditemukan. Dalam fase itu, filsafat ilmu dimaksudkan sebagai upaya menolak memaksaan kebenaran oleh dogma-dogma (agama, adat, mitos) tertentu. Sehingga dalam konteks tersebut (filsafat) ilmu, yang bempava memahami sesuatu secara hakiki (das ding unsich), dapat dinilai sebagai semangat kritisisme. Dengan demikian ilmu sebagai bebas nilai tidaklah berarti ilmu anti moral, melainkan anti dogmatik (Thomas Hidya, 2004, h. 18). Begitu juga secara epistemologis, seperti telah disinggung di atas bahwa verifikasi serta segenap metode pembuktian dalam ilmu merupakan "ilmu untuk ilmu", sehingga memungkinkan bagi seorang ilmuwan untuk bersikap hanya berdasarkan idealisme keilmuannya semata, lepas dari kepentingankepentingan.

Seolah dari dua persektif itulah kita mulai merasakan adanya jarak antara ilmu dan manusia; ilmu tidak bersentuhan dengan kehidupan manunsia, elitis. Namun dalam perspektif aksiologis, ilmu haruslah bersifat fungsional, dalam arti berfungsi bagi kehidupan manusia. Seperti sinergisasi teori-praktek dalam pengajaran Filsafat Pendidikan.

2 Einstein merupakan salah satu saintist yang terkenal dengan teori relativitasnya. Dia berseberangan dengan Newton dalam memahami empat unsur, zat, gerak, ruang, dan waktu. Menurut Einstein, empat unsur tersebut bersifat relatif, dan tidak bisa diukur secara absolut. Baca, University Paperbacks, Realitivity: The Special and The General Theory Albert Einstein, (London: Methuen, 1960). 
Jadi persoalan yang muncul di atas dapat dijawab dengan tegas, telah terjadi distorsi dalam pemahaman ilmu, yaitu sebatas ontologi dan epistemologi saja, sementara aksiologi ilmu yang menekankan fungsionalitasnya dalam kehidupan manusia, tidak diulas (Jujun S, 1986, h. 2). Sekali lagi perlu dipertegas, netralitas ilmu bukanlah berarti anti nilai, melainkan anti dogmatik. Hal ini dapat ditelusuri dalam pengalaman tradisi ilmiah Barat pada masa awal, yakni lahirnya Humanisme sebagai sikap terhadap dogmatisme agama Kristen Katolik. Artinya, hal ini membenarkan bahwa ilmu pengetahuan pada dasarnya tidak bekecenderungan menghilangkan "nilai", melainkan dogma agama yang tidak memberikan otonomi pada kebebasan berfikir.

Dari konklusi semacam inilah, Jujun S (1986, h. 101-105) mengajukan penyatuan ilmu alam dan ilmu sosial secara metodis untuk meningkatkan kualitas penelitian sosial yang kurang dikembangkan secara kuantitatif. Jujun beralasan, dikotomi ilmu alam dan ilmu sosial melahirkan penilaian bahwa ilmu alam lebih tinggi (sebagai high theory, dengan konsep yang sangat teoretis) dibanding ilmu sosial. Di samping pemetaan itu hanya akan membiarkan kedua jenis ilmu itu dalam kemandegan.

Begitu seterusnya perlu diupayakan pembudayaan ilmu dan metode ilmiah dengan melibatkan lembaga-lembaga pendidikan non-formal semisal museum dalam upaya pengembangan pengetahuan; sebagai upaya peleburan antara ilmu alam dan ilmu sosial itu. Demikian juga dengan nilai-nilai lainnya, agama, seni dan budaya. Peranan ilmu dalam pengembangan budaya sangatlah menonjol, bahwa ilmu adalah penggerak budaya menuju masyarakat yang transformatif.

\section{Gunung Es bernama Behavioralism Sciences}

Walau demikian, ada satu hal yang kurang disorot di atas, yaitu penilaian: saat nilai (kepentingan) dapat dihindari dalam ontologi dan epistemologi, lalu disimpulkan sebagai, ilmu bebas nilai. Bukankah keluar dari dogmatisme adalah sebuah kepentingan? Lepas dari kuasa mitos yang memperhambakan manusia terhadap alam, atau ilmu untuk menundukkan alam juga sebuah kepentingan? Di sinilah kritik terhadap netralitas ilmu dimulai.

Pemahaman ontologis (juga epistemologis) yang mengandaikan pemahaman sesuatu seperti halnya (das ding unsich) tidak lebih merupakan ilusi. Sebab,meminjam istilah Immanuel Kant, seperti yang dikutip oleh Aholiab Watlolypengetahuan manusia tentang sesuatu hanyalah fenomena, bukan benda itu sendiri, 
artinya, pengetahuan yang diindera hanyalah konstruksi "akal-akalan" dari rasio dan fenomena. (Aholiab, 2001, h. 75).

Dengan begitu tidak pernah ada otonomi pengetahuan dari rajutan relasi-relasi. Positivisme ilmu yang hanya menekankan kebenaran atau pengetahuan sebatas korespondensi antara indera dan nalar ditentang sebagai determinisme. Sebab pada akhirnya penilaian positivistik akan melahirkan absolutisme (Fransisco, 2004, h. 54-55), mengingat pengetahuan yang diperoleh dengan metode itu (diyakini) bersifat ahistoris/suprahistoris dan permanen; benda itu sendiri, kenyataan yang tidak terikat oleh perkembangan waktu dan merupakan kebenaran abadi.

Simpulnya, ada satu kecenderungan dalam ilmu dan metode ilmiah yang selama ini dicapai, yaitu positivisme deterministik. Dari penilaian ini kita juga dapat memposisikan pemikiran Jujun S (2006, h. 18-36) sebagai neo-postivisme, yang mencoba mengawinkan kedua ilmu, sosial dan alam dalam kerangka teoritis yang satu. Ia mengusulkan positivisasi ilmu sosial, untuk mengembangkannya secara kuantitatif, tanpa menyadari upaya yang ia tawarkan sebagai produksi ideologi status-quo (Pheni Chaled, 2006, h. 315-321).

Kesimpulan itu dapat dirinci, ilmu sosial yang lebih menekankan hubungan antara individu atau kelompok dengan yang lainnya, membutuhkan pemahaman dan bukan penilaian akan realitas yang sebenarnya. Sehingga penilaian secara kualitatif mutlak dibutuhkan. Namun Jujun S (1986, h. 325-334) merasakan adanya stagnasi pemikiran ilmu sosial dengan hanya membatasinya pada pendekatan kualitatif, atau yang disebut sebagai menurunnya pertumbuhan high level theory sebagai akibat dari konsentrasi pada empirical fact semata. Berbeda dengan penelitian kuantitatif yang mencoba membuat semacam rumusan umum tentang realitas yang dihadapi (Liek, 2004, h. 245).

Dapat diperhartikan dari determinisme yang terjadi dalam sosiologi modern, seperti dalam pemikiran Marx tentang dialektika masyarakat, yang menurutnya akan tercipta masyarakat komunistis dengan sendirinya, sebagai tuntutan alam yang pasti. Tidak lain, pemahaman ini hanya merupakan hasil penyikapan suatu realitas secara lahir, aspek instrumental, dalam arti kerja, dari suatu masyarakat. Konsep Marx inilah yang akhirnya dibekukan oleh Lenin dan Stalin sebagai doktrin komunisme Rusia. Atau dapat dicontohkan dengan demokrasi serta teori pembangunan oleh negara-negara 
Barat, yang meniscayakan kesejahteraan bagi negara yang menganut sistem tersebut. Akan tetapi kenyataan yang terjadi dalam masyarakat justru terciptanya masyarakat yang konservatif, penjaga stattus quo (Franz, 1992, h. 163).

Upaya Jujun dengan demikian dikhawatirkan akan terjebak pada determinisme ini, kendatipun ia menyadari pentingnya perspektif budaya. Oleh sebab itu, bahasan berikutnya akan mengulas hal ini, dengan di tambah dengan uraian perspektif Islam.

\section{Kritik ideologi; Narsisisme Epistemologis dan Ideologi Post-Modernisme}

Puncak dari krisis epistemologis ini mewujud dalam kolonialisasi dan imperialisasi dengan segala macam bentuknya. Dimaklumi kemudian jika pengetahuan bersifat ahistoris dan universal, ditambah sifatnya yang hakiki (das ding unsich) membuatnya semakin kuat untuk diterapkan di mana-mana, dalam hal ini ilmu yang tidak lain dari ide, telah berubah menjadi ideologi (John B., 2003, h. 17).

Contoh paling kongkrit adalah invansi Amerika Serikat ke Irak yang mengatasnamakan demokratisasi sebagai konsep yang harusnya ditiru oleh pemerintahan Irak. Demokrasi yang semula hanyalah sebuah hasil pengetahuan tentang sistem pemerintahan, karena dipahami secara positivistik, secara teipisah dari sejarah, universal; maka (dianggap) dapat dikembangkan di mana-mana sebagai ide(al)ologi rujukan. Tidak terkira bagaimana kerugian, kehancuran dan kematian yang mesti ditanggung dari invansi atas nama itu. Hal inilah yang memantik pertanyaan, mengapa perkembangan pengetahuan di negara-negara maju, cenderung menindas dan melemahkan negara yang lain (menengah-kecil). Begitulah sejarah kolonialisme dimulai.

Dari kenyataan itu dipahami, ternyata ada kepentingan dalam konsep-konsep Barat. Akan tetapi samakah dengan kepentingan yang dibahas dalam kajian ini, kepentingan yang dihapus oleh para filsuf abad modern? Marx memulai kritik ini lewat definisi ideologi sebagai camera obscura, cermin terbalik. Sebab baginya, ideologi hanyalah rekaman realitas yang terdistorsi; mengedepankan kelas mayoritas. Kebenaran adalah milik penguasa (Foucauit), karena kekuasaan ada di mana-mana, bukan karena menguasai segala-galanya (Mudji, 2004, h. 14).

Tentunya dapat dipahami bahwa positivisme adalah awal dari segala jenis kekerasan yang terjadi di era kontemporer ini, sehingga seluruh ideologi kontemporer 
(pragmatisme, madzhab Frankfurt, post-modernisme, post-feminimisme, postkolonialisme, etnometodologi, dll) memiliki musuh yang sama, positivisme.

Pragmatisme, yang didirikan oleh Charles S. Pierce, menekankan pentingnya pengkajian ulang terhadap metode yang selama ini dijadikan tolok ukur kebenaran, yaitu metode ilmiah. Sebab manusia lebih mementingkan bagaimana suatu pengalaman dapat dimaklumi sebagai ilmiah dengan melakukan pengujian berdasarkan pada kesesuaian dengan metode-metode tertentu, tanpa menyadari status metode itu sendiri (Aholiab, 2001, h. 101).

Pada dasarnya Pierce juga sepakat dengan korespondensi indra dan nalar, sepertri dalam logika Jujun, hanya saja ia mensyaratkan tiga langkah dalam logika ilmiahnya (lawan logika formal), yakni speculative grammar, yang mengkaji secara semiotis tentang relasi sign, object dan interpretant, yang digunakan untuk menolak kemandirian suatu proposisi, sebab ia selalu ada dalam bingkai relasi-relasi; kedua, critical logic dengan menekankan falibialitas abduktif yang menurutnya menghasilkan kebenaran yang bersifat tentatif; dan ketiga, speculative rethoric tentang kesesuaian antara simbol dan maknanya. Sekali lagi, bahwa kebenaran yang diperoleh hanya bersifat tentatif; benar selagi belum ditemukan alasan yang menyalahkannya. Teori ini disebut juga sebagai falsitikasi yang kemudian dikembangkan oleh Kari Raimund Popper (Rodiyah, 2007, h. 125).

Cukup jelas bagi pragmatisme Pierce, sinyalemen universalitas kebenaran serta kemandiriannya tidak dapat diterima. Berkenaan dengan universalitas, mengajukan kriteria yang menjamin kebenaran tidak salah adalah kesalahan itu sendiri, karena sewenang dengan universalitas itu. Yang dimaksud di sini adalah klaim ahistoris dan permanen yang memuat kepentingan status-quo.

Sedangkan tentang kemandirian ilmu, Habermas menegaskan, tak satupun kebenaran/pengetahuan lepas dari kepentingan-kepentingan kognitif yang terselimuti dalam tujuan ilmu itu sendiri. Kajian semiotik-hermeneutik sangat dibutuhkan untuk menyingkap kepentingan itu, untuk semaksimal mungkin menghindari terjadinya distorsi menjadi kepentingan instrumental, yang akhirnya mengarah pada absolutisme dan kolonialisme. Inilah kepentingan yang dikritik oleh Marx dengan Camera Obscuranya (Fransisco, 2004, h. 230-233). 
Dalam konsteks kajian ilmu sosial, generalisasi dan universalisme tidak lagi dapat dipertahankan mengingat objek sosial adalah manusia yang aktif, bukan manusia dalam arti fisik(a) ataupun biologi(s). Pemaduan metode ilmiah antara ilmu alam dan sosial, seperti dalam tawaran Jujun S, telah melahirkan anarki epistemologis bahkan kolonialisme metodologis, dengan metode generalisasi distorsif.

Untuk itu lahirlah berbagai metode semisal konstruktivisme, historisme, refleksivitas, indeksikalitas dan konsep anggota (etnometodolgi) ${ }^{3}$, dekonstuksi (PostModernisme) ${ }^{4}$, epistemologi stand-point ${ }^{5}$ (feminimisme), pengetahuan dan kuasa, oposisi biner, hibriditas dan subaltern (post-koionialisme).

\section{Budaya Menilai (pem)Budava(an) Ilmu}

Cukup telak kritik terhadap logiko hipotetiko verifikatif, metode yang diangkat Jujun S dalam banyak tulisannya; bahwa akhirnya ia terjebak dalam determinisme keilmuan yang bercorak behavioralism sciences, dalam arti Jujun S lebih tertarik memahami ilmu sebagai fenomena lahiriyah, dengan fisikalisasi ilmu sosial. Model inilah yang dibantah tuntas oleh ideologi kontemporer sebagai reduksionisme pengetahuan.

Lebih dari sekedar itu, kritik rasio Immanuel Kant dapat dianggap sebagai metode yang berjasa dalam upaya pengembangan ilmu (relevan dengan kajian aksiologis ini), yaitu tidak membiarkan metode ilmiah tanpa kritik, dengan menilai pengetahuan manusia "sebagai ilmu" karena sesuai dengan metode ilmiah, melainkan juga dengan mengkritisi validitas metode ilmiah sebagai produksi kebenaran (ilmu) (Franz, 1992, h. 104-110).

\footnotetext{
${ }^{3}$ Etnometdodologi dapat dipahami sebagai aliran sosiologi yang menolak positivisme ilmu sosial dengan menekankan keunikan manusia (masyarakat) yang tidak bisa direduksi dalam teori (sosial) umum. Pendekatan refleksivitas, indeksikalitas dan konsep anggota menggambarkan penolakan universalitas itu. Dengan konstruktivisme mereka menolak determinsme sosial. Aliran ini dielopori oleh Harold Garfinkel. Baca Alain Colon. Etnometodologi. terj. Jimmy Ph. PAT, (Nusa Tenggara Barat: Yayasan Lengge, 2004), cet. II

${ }^{4}$ Istilah dekonstruksi dipopulerkan oleh Jacques Derrida yang berintikan penghancuran logosentrisme (reduksi monistik) dalam filsafat. Muhammad Al-Fayyadl, Derrida, (Yogyakarta: LKNS, 2005)

${ }^{5}$ Epistemologi (feminis) Stand-Point dimaksudkan sebagai uaya menuju keutuhan pengetahuan yang terdistorsi oleh patriarkalisme pengetahuan, seperti dalam ulasan Braidotti, bahwa pengalaman perempuan bukanlah dasar yang valid sebagai konstruksi ilmu. Dengan begitu epistemologi stand-point, meminjam istilah Homi K. Bhaba, akan keluar dari pencitraan dengan mendialektikakaknnya dengan bangun keilmuan yang ada; menuju keutuhan pengetahuan. Tokoh pertama dalam Eistemologi ini adalah Sandra Harding. Akhyar Yusuf Lubis, Dekonstruksi Epistemologi Modern; Dari Post-modernisme, Teori Kritis. Poskolonialisme hingga Cultural Studies, (Jakarta: Pustaka IndonesiaSatu, 2006)
} 
Pemahaman ilmu memang tidak bisa difokuskan (apalagi dicukupkan) pada aspek epistemologis (juga ontologis) saja, yang menekankan netralitas ilmu, melainkan juga aspek aksiologis yang merupakan jembatan antara idelitas ilmu dengan kepentingan manusia. Dan memang terbukti bahwa ilmu tidak pernah bebas nilai (kepentingan). Sebab, tujuan-tujuan yang diperoleh dari ilmu adalah kepentingan yang dimaksud, kepentingan kognitif, sesuai dengan tingkat kesadaran dan kebutuhan masyarakatnya.

Fokus pendidikan di era globalisasi, harusnya membuka paradigma kritik terhadap eksploitasi kepentingan kognitif oleh kepentingan politis-ekonomis yang cenderung merugikan; baik oleh kolonialisme internasional maupun kolonialisme lokal. Paradigma kritik tidak lain akan terbentuk dengan memahami ilmu sebagai kritik sosial, sebagai proses mencari kebenaran, bukan jenis pengetahuan.

Dan dalam rangka pembangunan manusia seutuhnya, perluasan perspektif adalah satu keharusan, agar mampu melepaskan diri dari determinisme keilmuan. Inilah yang patut dibudayakan dalam masyarakat, demi terciptanya sebuah masyarakat ilmiah, yaitu masyarakat yang memandang ilmu bukan hanya sebagai yang disistematisir dalam buku, tetapi sebagai model dan cara hidupnya.

Dalam keadaan inilah, logika Islamisasi relevan untuk dimunculkan, paling tidak dapat dijadikan tawaran dalam memberikan persektif tentang keutuhan manusia di tengah krisis kemanusiaan dan tradisi keilmiahan.

\section{Epistemologi Islam; Sebuah Alternatif}

Dari ulasan di atas, kita sudah menemukan beberapa poin permasalahan. Setidaknya terdapat dua aspek yang perlu diperhatikan. Pertama, secara teoretis, krisis kemanusiaan dalam masyarakat modern, disebabkan kemajuan ilmu pengetahuan, dan salah satu faktor penentunya adalah epistemolgi yang menekankan bebas nilai. Kedua, secara pragmatis, terletak pada manusianya sebagai aktor pengembangan ilmu pengetahuan, dalam hal ini adalah moralitas dan tanggung jawab ilmuwan dan manusia sebagai aktor, sekaligus pengguna dari hasil ilmu pengetahuannya.

Berbicara dua aspek ini, pada dasarnya, tradisi ilmiah Islam dapat menjadi alternatif, sekaligus dapat menjadi solusi dari krisis yang dialami oleh masyarakat modern dan tradisi ilmiah Barat. Mulyadhi Kartanegara (2007, h. 15), menyatakan bahwa tidak ada seorang ilmuwan muslim yang mengkaji dan meneliti alam hanya demi 
melunaskan rasa ingin tahu saja. Tapi, mereka semua melakukan dalam rangka mencari jejak ilahi.

Mencari jejak ilahi seperti yang tekankan Mulyadhi, setidaknya menjadi satu pembeda dari tradisi ilmiah Barat, yang menekankan realitas empiris sebagai pondasinya. Dan kalau kita perhatikan, tradisi barat pada dasarnya tidak memiliki tujuan, karena meletakkan "keingintahuan" sebagai tujuannya. Wajar, kalau dalam tradisi Barat, langkah pertama dalam meneliti adalah "meragukan segala sesuatu".

Sayangnya, sejarah masyarakat modern berakhir pada krisis moral. Salah satu faktor pendorongnya adalah prinsip epistemologi "bebas nilai'". Hal inilah yang ingin dibenahi dalam tradisi ilmiah Islam. Dalam konteks inilah, Islamisasi berfungsi, di satu sisi ingin menawarkan epitemolgi Islam, yang dapat dijadikan alternatif metodis fondasional dalam mengembangan ilmu pengetahuan. Di sisi lain, memberikan tawaran dalam membentuk manusia seutuhnya.

Muzammil Qomar (2005, h. 48) juga menemukan kecenderungan ini. Menurutnya, ketika umat Islam dihadapkan dengan sains modern dan krisis yang dibawanya, Umat Islam cenderung melakukan Islamisasi ilmu pengetahuan dengan tujuan meluruskan penyimpangan-penyimpangan yang diakibatkannya. Dengan demikian, Islamisasi dapat dijadikan alternatif dalam konteks seperti ini.

Secara epistemologis, tradisi ilmiah Islam tidak didasarkan pada objek yang diteliti, melainkan pada sumber. Hai inilah yang mendorong perbedaan epistemologi Islam dan epistemologi Barai. Mulyadhi (2007, h. 183) dalam hal ini memaparkan perbedaan keduanya. Epistemologi Barat membatasi pada bidang empiris, sedangkan dalam tradisi Islam, tidak dibatasi hanya pada bidang fisik, tapi juga non-fisik.

Atas dasar inilah, Islam menawarkan salah satu pendekatannya, yang dikenal dengan metode Irfani. Metode ini pada intinya, menekankan pengalaman. Artinya, proses penelitian dalam tradisi ilmiah Islam tidak berhenti sebatas mengetahuinya, meskipun sudah dibuktikan dengan beberapa pembuktian empiris. Tapi, hal itu belum tentu terjamin kebenarannya (Mulyadhi, 2007, h. 192). Terbukti, indra sebagai alat pembuktian dalam tradisi Barat memiliki banyak kekurangan, salah satunya adalah tidak mengakui kebenaran dalam keyakinan keagamaan. Padahal, agama adalah sebuah kebenaran, seperti, beberapa peristiwa yang ditemukan oleh Ilmuwan Barat, sudah terjelasakan dalam Al-Qur'an, seperti peneiptaan manusia dan alam. 
Penjelasan semacam ini, memang tidak berkaitan secara langsung dengan persoalan moral dan tradisi ilmiah Barat, tapi yang menjadi acuan dalam hal ini adalah, tradisi ilmiah Islam berangkat dari keyakinan keagamaan, agama dalam hal ini lekat dengan nilai-nilai spiritual maupun moral. Dengan demikian, tradisi ilmiah Islam memposisikan agama sebagai batasan dalam meneliti. Dengan kata lain, sebuah proses penelitian selalu akan dipertimbangan dengan nilai-nilai moral dalam agama, sebagai pijakannya. Seperti yang telah ditekankan di atas, bahwa ilmuwan Islam dalam proses meneliti adalah untuk menemukan jejak-jejak Ilahi. Maka, menjadi tidak logis, apabila dalam proses meneliti mengesampingkan tujuan tersebut dan mengabaikan nilai-nilai moral.

Atas dasar ini, kita dapat menegaskan bahwa mengakui agama (nilai-nilai spiritual dan moral) sebagai salah satu sumber dalam penelitian ilmiah, maka secara bersamaan juga dalam mengantarkan manusia atau ilmuwan pada khusunya untuk mengembankan totalitas pengetahuan, yang disejalankan nilai-nilai kemanusiaan. Akhirnya, epistemologi Islam yang meletakkan nilai-nilai spritual dan moral (agama) dapat dijadikan alternatif dalam mengembangkan tradisi ilmiah, dan membentuk kemanusiaan seutuhnya, yakni ilmuwan yang selalu mempertimbangan aspek moral dalam menghasilkan sebuah penelitian.

\section{Kesimpulan}

Dari ulasan di atas, ditemukan bahwa perkembangan ilmu pengetahuan Barat, dan positivisme sebagai landasannya, telah melahirkan krisis moral dalam masyarakat dan melahirkan manusia yang timpang, tidak utuh dalam memahami pengetahuan yang sebenarnya. Selain itu, tulisan ini juga menunjukkan bahwa pola pikir positivis menjauhkan manusia dari realitas kemanusiaannya. Akhirnya, tradisi penelitian tidak mengindahkan unsur kemanusiaan. Padahal, manusia ditinjau dari aspek apapun, adalah hal yang harus dimuliakan. Akibat lainnya adalah terjadinya determinisme pengetahuan dalam masyarakat.

Salah satu pendorong lahirnya krisis seperti ini, dalam tulisan ini ditunjukkan bahwa epistemologi "bebas nilai" yang banyak disalah pahami sebagai satu kebebasan penelitian ilmiah dari nilai-nilai moral. Padahal, bebas nilai dalam konteks histerisnya, adalah bebas dari dogmatisme agama yang mengungkung manusia untuk tidak merdeka dalam berfikir. Dari sini, epistemologi Islam dapat dijadikan alternatif yakni 
mendasarkan pengetahuan dan ilmuwan dalam koridor nilai-nilai spritual dan nilai-nilai moral, selain itu, dalam peroses penelitian, tidak didasarkan pada objek pengetahuan empiris, melainkan dari sumbernya, yakni wahyu. Dengan cara demikian, krisis moral dapat teratasi dan tradisi ilmiah tetap dapat dipertahankan dan dikembangkan. Akhirnya secara tidak langsung, hal itu dapat melahirkan masyarakat yang utuh dan manusia yang utuh.[]

\section{Daftar Pustaka}

Al-Fayyadi, Muhammad. 2005. Derrida. Yogyakarya: LKiS.

Budiharman, Fransisco. 2004. Kritik Ideologi; Menyingkap Kepentingan Pengetahuan Bersama Juergen Habermas. Yogyakarta: Bukubaik.

Chaled, Pheni. 2006. Teori dan Isu Pembangunan. Jakarta: Universitas Terbuka.

Garfinkel, Harold, Alain Colon. 2004. Etnometodologi, terj. Jimmy Ph. PAT. Nusa Tenggara Barat: Yayasan Lengge.

Hadiwardoyo, Purwa. 1990. Moral dan Masalahnya. Yogyakarta: Kanisius.

Khuza'i, Rodiyah. 2007. Dialog Epistemologi Muhammad Iqbal dan Charles Peirce. Bandung: Refika Aditama.

Kukla, Andre. 2006. Konstruktivisme Sosial dan Filsafat Ilmu, terj. Hari Kusharyanto. Yogyakarta: Jendela.

Lubis, Akhyar Yusuf. 2006. Dekonstruksi Epistemologi Modern; Dari PostModernisme, Teori Kritis, Poskolonialisme hingga Cultural Studies. Jakarta: Pustaka Indonesia Satu.

Paperbacks, University. 1960. Realitivity; The Special and The General Theory Albert Einstein. London: Methuen.

Puespoardojo, S. 1989. Strategi Kebudayaan. Jakarta: Gramedia.

Suriasumantri, Jujun S. 2005. Filsafat Ilmu, Sebuah Pengantar Populer. Jakarta: Pustaka Sinar Harapan.

Suriasumantri, Jujun S. 1986. Ilmu dalam Perspektif Moral, Sosial, dan Politik; Sebuah Dialog dengan Keilmuan Dewasa Ini. Jakarta: Gramedia.

Suriasumantri, Jujun S. 2006. Ilmu dalam Perspektif. Yogyakarta: Yayasan Obor Indonesia.

Suseno, Franz Magnis. 1992. Filsafat Sebagai Ilmu Kritis. Yogyakarta: Kanisius.

Sutrisno, Mudji, Hendar Putranto (ed). 2004. Hermenutika Pasca Kolonial. Yogyakarta: Kanisius.

Thomson, John B. 2003. Analisis Ideologi; Kritik Wacana Ideologi-ideologi Dunia, terj. Haqquyl Yaqin. Yogyakarta: IRCiSOD.

Watloly, Aholiab. 2001. Tanggung Jawab Pengetahuan; Mempertimbangkan Epistemologi Secara Kultural. Yogyakarta: Kanisius. 